\section{Trinexapac-ethyl Effects on Stolon Activity and Node Vitality of 'Tifway' Hybrid Bermudagrass}

\author{
Marco Volterrani, Simone Magni, Monica Gaetani, \\ and Filippo Lulli ${ }^{1}$
}

ADDITIONAL INDEX WORDS. plant growth regulators, growth suppression, recovery potential, translocation

Summary. The stoloniferous-rhizomatous growth habit of bermudagrass [Cynodon dactylon (L.) Pers.] is a key feature for fast turf establishment and effective recovery from wear and divots. Trinexapac-ethyl (TE) is a plant growth regulator used extensively to reduce the need for mowing. However, vertical growth suppression of vertical growth has the potential to reduce horizontal growth. Furthermore, side effects reported on several physiological functions could affect node ability to generate new plants. In a greenhouse trial, 'Tifway' hybrid bermudagrass $(C$. dactylon $\times$ C. transvaalensis Burtt Davy) grown in pots was treated with increasing rates of TE (untreated control, $0.015,0.075,0.150$, and $0.300 \mathrm{~g} \cdot \mathrm{m}^{-2}$ ). The treatment effects on the number of stolons produced and their linear growth rate, node production, node vitality, and daughter plant characteristics were investigated. The effects of growth inhibition because of TE application on nodes and daughter plants and the relative duration were also assessed. Starting from 2 weeks after treatment ( 2 WAT), TE application resulted in reductions of stolon length of $24.6 \%$ and $52.9 \%$ compared with the untreated control, while at 3 and 4 WAT only 0.150 and $0.300 \mathrm{~g} \cdot \mathrm{m}^{-2}$ application rates produced significant reductions in stolon length with values of $37.1 \%$ and $52.9 \%$ at 3 WAT and of $34.1 \%$ and $48.3 \%$ at 4 WAT, respectively. The number of nodes per stolon was unaffected by treatments. No effect was observed in node vitality but daughter plants showed a postinhibition growth enhancement when nodes were excised at 4 WAT. TE application at the labeled rate did not affect the number of stolons produced by 'Tifway' hybrid bermudagrass compared with untreated control, while a reduction in stolon growth rate was recorded only at 2 WAT. Application at higher rates reduced stolon growth rate longer than labeled rate but not stolon production. None of the treatments reduced the number of vital nodes. Application rates higher than labeled rate produced a postinhibition growth enhancement in plants that originated from nodes excised at 4 WAT.

$\mathrm{B}$ ermudagrass is the most used warm season turfgrass for sports and ornamental purposes wherever climatic conditions sustain its growth (Richardson, 2002). The stoloniferousrhizomatous growth habit and the aggressiveness of bermudagrass are key features enabling quick establishment by vegetative propagation and allow turf to promptly recover from wear and divots (Beard, 1973). While it is appreciated for establishment and recovery, a vigorous growth is considered a drawback for routine maintenance since frequent mowing and verticutting are required to maintain

Department of Agronomy and Management of the Agroecosystem, Centre for Research on Turfgrass for Environment and Sports (CeRTES), University of Pisa, 2 Via San Michele degli Scalzi, 56124 Pisa, Italy

The present research was funded by the Italian Ministry for Agricultural and Forestry Policies, within the Project "Advanced systems for greenhouse production of warm season turfgrass species for multiple water-saving and energy-efficient applications" (2010-11).

${ }^{1}$ Corresponding author. E-mail: flulli@agr.unipi.it. high quality standards (Waltz and Whitwell, 2005).

Chemical growth suppression artificially reduces vertical plant growth to reduce mowing frequency. Since its release in 1991 for turfgrass use, TE has become an increasingly popular plant growth regulator (Ervin and Zhang, 2008).

TE is foliar absorbed and its intended action is to reduce cell elongation by inhibiting gibberellic acid biosynthesis, at a late stage. In particular, gibberellic acid biosynthesis is stopped between $\mathrm{GA}_{1}$ and its inactive precursor $\left(\mathrm{GA}_{20}\right)$. The reduced concentration of $\mathrm{GA}_{1}$ reduces shoot elongation thus producing the desired effect of growth suppression (Ervin and Zhang, 2008).

Besides the reduction of vertical growth, the effects of TE application on bermudagrass stolon growth have been documented. In a field trial carried out by Fagerness and Yelverton (1998), they described a decreased stolon length in TE-treated bermudagrass stands, with stolon number being unaffected. In two experiments carried out in a controlled environment, Fagerness and Yelverton (1999) reported little impact on stolon number and length with no effect on stolon biomass while Fagerness et al. (2002) observed a higher number of stolons on TE-treated plants.

In a 2-year study, inconsistent effects through the years on morphological parameters such as stolon density and stolon internode length were also reported by Richardson (2002). McCarty et al. (2011) reported a minimal impact of TE on lateral regrowth of 'TifEagle' hybrid bermudagrass.

Several other effects have been documented following the application of TE on bermudagrass. A quality enhancement of ultradwarf bermudagrasses was recorded on salt-stressed turf (Baldwin et al., 2006) and in reduced light conditions (Baldwin et al., 2009; Bunnel et al., 2005). Williams et al. (2010) reported an increased tolerance to simulated traffic and enhanced quality of six bermudagrass cultivars as a result of TE application. Better fall color retention and faster spring green-up were reported on hybrid bermudagrass treated during the growing season (Richardson, 2002). Enhanced shoot density was described by Fagerness et al. (2001), while inconsistent results were found for freezing tolerance of TE-treated bermudagrass (Fagerness et al., 2002; Richardson, 2002).

\begin{tabular}{llll}
\hline $\begin{array}{l}\text { Units } \\
\text { To convert U.S. to SI, } \\
\text { multiply by }\end{array}$ & U.S. unit & SI unit & $\begin{array}{l}\text { To convert SI to U.S., } \\
\text { multiply by }\end{array}$ \\
\hline 3.7854 & gal & $\mathrm{L}$ & 0.2642 \\
4.5273 & gal $/ \mathrm{yard}^{2}$ & $\mathrm{~L} \cdot \mathrm{m}^{-2}$ & 0.2209 \\
2.54 & inch $(\mathrm{es})$ & $\mathrm{cm}$ & 0.3937 \\
25.4 & inch $(\mathrm{es})$ & $\mathrm{mm}$ & 0.0394 \\
1.1209 & lb/acre & $\mathrm{kg} \cdot \mathrm{ha}^{-1}$ & 0.8922 \\
28,350 & $\mathrm{oz}$ & $\mathrm{mg}$ & $3.5274 \times 10^{-5}$ \\
33.9057 & $\mathrm{oz} / \mathrm{yard}^{2}$ & $\mathrm{~g} \cdot \mathrm{m}^{-2}$ & 0.0295 \\
$\left({ }^{\circ} \mathrm{F}-32\right) \div 1.8$ & ${ }^{\circ} \mathrm{F}$ & ${ }^{\circ} \mathrm{C}$ & $\left(1.8 \times{ }^{\circ} \mathrm{C}\right)+32$ \\
& & &
\end{tabular}


Based on the description of several secondary effects, it has become evident that different metabolic pathways are affected in the plant following TE application. Reduced cell elongation results in a higher chloroplast density and a higher photosynthetic net assimilation at canopy level. Enhanced production of total nonstructural carbohydrates (TNC) is coupled with a lower TNC demand because of reduced cell elongation, thus generating an excess of TNC redirected to the basal portion of plants where root activity is stimulated. Enhanced root activity promotes cytokinin production which in turn stimulates the formation of new stems from crowns. Therefore, inhibition of $\mathrm{GA}_{1}$ seems to be the start of a chain of metabolic events that ultimately lead to the modification of some physiological functions (Ervin and Zhang, 2007, 2008).

Node tissue formation occurring under the effect of TE and altered physiological functions could be associated with modifications in subsequent plant stages such as node sprouting and daughter plant development. Based on this assumption, the purpose of this study was to investigate: 1) TE effects on plants stolon production, stolon growth rate, and node production after a single application and during the period of TE effectiveness, 2) the effect of TE, secondary products, or both on node vitality and daughter plant characteristics, and 3) to assess whether the aforementioned effects on nodes were permanent or transient and if a gradient could be detected throughout the stolon length.

\section{Materials and methods}

A greenhouse study was carried out from May to Sept. 2011 in Pisa, Italy (lat. $43^{\circ} 47^{\prime} \mathrm{N}$, long. $10^{\circ} 25^{\prime} \mathrm{E}$ ). Growing conditions were as follows: minimum air temperature range: $18 \pm$ $3{ }^{\circ} \mathrm{C}$; maximum air temperature range: $37 \pm 3^{\circ} \mathrm{C}$, and natural sunlight. On 27 May 2011, sprigs of 'Tifway' hybrid bermudagrass were collected from a mature stand and propagated in $20-\mathrm{cm}^{-}$ diameter plastic pots ( 5 L volume) filled with a commercial greenhouse mix (peat-based propagation substrate Type 3 Special; Gebr. Brill Substrate, Georgsdorf, Germany). Pots were maintained in controlled greenhouse conditions. To obtain the establishment of a dense turf cover in all pots,
$9 \mathrm{~mm}$ of water were applied daily and mowing was carried out weekly at $2.5 \mathrm{~cm}$ cutting height. On 23 June 2011 , the turf was mowed at $2.5 \mathrm{~cm}$ height and all the horizontal stems growing outside the pot were trimmed back to the pot rim with scissors. The following day, pots were treated with five increasing rates of TE (Primo Maxx; Syngenta, Greensboro, NC): 1) untreated control, 2) $0.015 \mathrm{~g} \cdot \mathrm{m}^{-2}$ (labeled rate for 'Tifway' with a cutting height of $\left.2.5 \mathrm{~cm}), 3) 0.075 \mathrm{~g} \cdot \mathrm{m}^{-2}, 4\right)$ $0.150 \mathrm{~g} \cdot \mathrm{m}^{-2}$, and 5) $0.300 \mathrm{~g} \cdot \mathrm{m}^{-2}$. Foliar applications were delivered with a carbon dioxide $\left(\mathrm{CO}_{2}\right)$ sprayer at a volume of $0.1 \mathrm{~L} \cdot \mathrm{m}^{-2}$. After treatment, irrigation was suspended for $24 \mathrm{~h}$ to allow absorption of $\mathrm{TE}$ by leaves (Huang, 2007). Experimental design was a randomized complete block with four replications. The trial was carried out in unmowed conditions. Irrigation was applied daily with an automated overhead boom system delivering a total amount of $9 \mathrm{~mm}$ of water. Liquid fertilization was applied weekly using alternatively $30 \mathrm{~N}-4.3 \mathrm{P}-8.3 \mathrm{~K}$ and $9 \mathrm{~N}-$ 6.5P-24.9K soluble fertilizers (Grow More, Gardena, CA), and the following total amounts of nutrients were distributed during the trial period: $126 \mathrm{~kg} \cdot \mathrm{ha}^{-1} \mathrm{~N}, 27 \mathrm{~kg} \cdot \mathrm{ha}^{-1} \mathrm{P}$, and $71 \mathrm{~kg} \cdot \mathrm{ha}^{-1} \mathrm{~K}$.

From 2 WAT, new stolon growth exceeded the pot rim and TE effects were monitored until 4 WAT (Fagerness and Yelverton, 2000; Fagerness et al., 2004). Starting from 2 WAT the following measurements were carried out:

1) Number of stolons per pot and weekly stolon production per pot: Stolons exceeding the pot rim were counted on a weekly basis from 2 to 4 WAT. The cumulated number per pot was reported as number of stolons per pot, while additional stolons counted on each pot were reported as "weekly stolon production."

2) Stolon length and solon growth rate: At 2 WAT, four stolons per pot were labeled for subsequent identification. From 2 to 4 WAT, stolon length was measured with a ruler from first leaf insertion to pot rim. Data were reported as stolon length and weekly increments were reported as stolon growth rate.

$3)$ Number of visible nodes: From 2 to 4 WAT, nodes were counted on the stolons labeled for length measurement. The cumulated number was reported as "node number per stolon," while weekly increments in node number were reported as "node production per stolon".

4) Node vitality: To collect stolons that originated at the same time, eight stolons per pot were labeled at 2 WAT. Four were collected at 4 WAT and the remaining four at 8 WAT. Stolons collected at 4 WAT were representative for the evaluation of TE application effects, while stolons collected at 8 WAT were considered representative for the evaluation of the residual effects of TE beyond the expected duration of growth suppression. Nodes were excised from stolons and subsequently transplanted in 120-cell polystyrene seed trays filled with the same greenhouse mix used to fill the pots. Trays were maintained for 4 weeks in the greenhouse with the same environmental conditions as for pots. On a weekly basis, vital nodes were counted and the vital node percentage calculated. Nodes that failed to generate green tissues after a 4-week period were considered nonvital. Four weeks after node were transplanted in the seed trays on daughter plants originated from nodes used for determining node vitality the following parameters were determined: a) color (assessed visually and reported with a 1 to 9 scale with $1=$ light green, $9=$ dark green), b) number of leaves per plant (assessed by direct counting), c) plant height (measured with a ruler from soil level to the highest leaf tip), and d) plant dry biomass [measured by weighing collected and oven dried (80 ${ }^{\circ} \mathrm{C}$ until constant weight) plant aerial parts].

To assess the effects of translocation of TE or secondary products from absorption site to newly generated organs, nodes excised from each single stolon were assigned to one row of cells and positioned with the same sequence as they were generated in the parent stolon. With this procedure, any detectable gradient in node vitality or daughter plant characteristic could be attributed to TE or secondary product translocation.

Data were subject to analysis of variance using CoStat (version 6.400; CoHort Software, Monterey, CA) and separation of means was performed with a Fisher's protected least significant difference test at a $5 \%$ probability level. 


\section{Results}

Under trial conditions, the following parameters (recorded at 1,2 , 3 , and 4 WAT) were unaffected by TE application rates (data not shown): number of stolons per pot (and hence weekly stolon production rate) and node number per stolon (and hence weekly node production rate). Starting from 2 WAT, TE applied at labeled rate $\left(0.015 \mathrm{~g} \cdot \mathrm{m}^{-2}\right)$ resulted in a significant reduction in mean stolon length compared with the untreated control $(14.4$ and $19.1 \mathrm{~cm}$, respectively) (Table 1). Application rate of $0.075 \mathrm{~g} \cdot \mathrm{m}^{-2}$ provided an equivalent effect to the labeled rate. Application rates of 0.15 and $0.3 \mathrm{~g} \cdot \mathrm{m}^{-2}$ produced a further significant reduction in stolon elongation compared with $0.015 \mathrm{~g} \cdot \mathrm{m}^{-2}(9.5$ and $9.0 \mathrm{~cm}$, respectively) with no statistical difference between the effect of the three highest rates. At 3 and $4 \mathrm{WAT}$, the 0.015 - and $0.075-\mathrm{g} \cdot \mathrm{m}^{-2}$ treatments did not induce a significant growth suppression in stolons compared with the untreated control, while the 0.15and $0.3-\mathrm{g} \cdot \mathrm{m}^{-2}$ treatments reduced mean stolon length from $25.9 \mathrm{~cm}$ in the control to 16.3 and $12.2 \mathrm{~cm}$, respectively, at $3 \mathrm{WAT}$; and from $31.7 \mathrm{~cm}$ (control) to 20.9 and $15.3 \mathrm{~cm}$, respectively, at 4 WAT. At both dates, the effect recorded for the application of TE at $0.15 \mathrm{~g} \cdot \mathrm{m}^{-2}$ was not different from $0.015-\mathrm{g} \cdot \mathrm{m}^{-2}$ rate treatment.

Differences in stolon length were produced by differences in stolon growth rate that were statistically significant only at 2 WAT (Table 1 ). At this date, stolon growth suppression was clearly directly related to TE application rate with the control exhibiting the fastest elongation $(9.6 \mathrm{~cm} /$ week), followed by a significant reduction caused by the 0.015 - and $0.075-\mathrm{g} \cdot \mathrm{m}^{-2}$ application rates $(7.2$ and $6.2 \mathrm{~cm} /$ week, respectively). A further significant reduction in growth rate was produced by the 0.15 - and $0.3-\mathrm{g} \cdot \mathrm{m}^{-2}$ application rates with no statistical difference between the two rates $(4.8$ and $4.5 \mathrm{~cm} /$ week, respectively).

Nodes excised from parent stolons showed a high vitality with no statistical differences between TEtreated plants and the untreated control (Table 2). On average, daughter plants originated from $98 \%$ and $95 \%$ of nodes collected at 4 and 8 WAT,

Table 1. Mean stolon length and stolon growth rate of 'Tifway' bermudagrass treated with different rates of trinexapac-ethyl (TE) Measurements taken at 2, 3, and 4 weeks after treatment (WAT) on a sample of four stolons per pot.

\begin{tabular}{lcccccccc}
\hline & \multicolumn{3}{c}{ Mean stolon length $(\mathbf{c m})^{\mathrm{z}}$} & & \multicolumn{3}{c}{ Stolon growth rate $(\mathrm{cm} / \text { week })^{\mathrm{v}}$} \\
\cline { 2 - 4 } \cline { 6 - 8 } $\begin{array}{c}\text { TE application } \\
\text { rate }\left(\mathbf{g} \cdot \mathbf{m}^{-2}\right)^{\mathrm{z}}\end{array}$ & $\mathbf{2}$ & $\mathbf{3}$ & $\mathbf{4}$ & & $\mathbf{2}$ & $\mathbf{3}$ & $\mathbf{4}$ \\
\hline Control & 19.1 & 25.9 & 31.7 & & 9.6 & 6.8 & 5.8 \\
0.015 & 14.4 & 22.2 & 29.0 & & 7.2 & 7.8 & 6.8 \\
0.075 & 12.3 & 18.7 & 23.5 & & 6.2 & 6.4 & 4.8 \\
0.150 & 9.5 & 16.3 & 20.9 & & 4.8 & 6.8 & 4.6 \\
0.300 & 9.0 & 12.2 & 15.3 & & 4.5 & & 3.2 & 3.1 \\
LSD $(0.05)^{\mathrm{y}}$ & 4.2 & 7.9 & 10.4 & & 2.1 & & - & - \\
$P$ & $* *$ & $*$ & $*$ & & $* *$ & & NS & NS \\
\hline
\end{tabular}

${ }^{\mathrm{z}} 1 \mathrm{~g} \cdot \mathrm{m}^{-2}=0.0295 \mathrm{oz} / \mathrm{yard}^{2}, 1 \mathrm{~cm}=0.3937$ inch.

Least significant difference at $P=0.05$

${ }^{*}{ }^{* *}$ Significant at $P \leq 0.05$ and $P \leq 0.01$, respectively; NS $=$ not significant at $P \leq 0.05$

Table 2. Percent node vitality and daughter plant biomass of 'Tifway' bermudagrass treated with different rates of trinexapac-ethyl (TE). Nodes were excised from stolons 4 and 8 weeks after treatment (WAT) and biomass of daughter plants determined after a 4 -week growing period.

\begin{tabular}{|c|c|c|c|c|}
\hline \multirow{3}{*}{$\begin{array}{l}\text { TE application } \\
\text { rate }\left(\mathrm{g} \cdot \mathrm{m}^{-2}\right)^{\mathrm{z}}\end{array}$} & \multirow{2}{*}{\multicolumn{2}{|c|}{$\frac{\text { Node vitality (\%) }}{\text { WAT }}$}} & \multirow{2}{*}{\multicolumn{2}{|c|}{$\begin{array}{l}\text { Daughter plants aboveground } \\
\text { biomass (mg/plant dry wt) } \\
\text { WAT }\end{array}$}} \\
\hline & & & & \\
\hline & 4 & 8 & 4 & 8 \\
\hline Control & 98 & 95 & 73.3 & 43.7 \\
\hline 0.015 & 100 & 98 & 62.2 & 47.5 \\
\hline 0.075 & 99 & 96 & 98.5 & 58.2 \\
\hline 0.150 & 96 & 93 & 94.3 & 44.5 \\
\hline 0.300 & 99 & 95 & 94.4 & 58.6 \\
\hline LSD $(0.05)^{\mathrm{y}}$ & - & - & 14.9 & - \\
\hline$P$ & NS & NS & $* * *$ & NS \\
\hline
\end{tabular}

${ }^{2} \mathrm{l} \mathrm{g} \cdot \mathrm{m}^{-2}=0.0295 \mathrm{oz} / \mathrm{yard}^{2}, \mathrm{l} \mathrm{mg}=3.5274 \times 10^{-5} \mathrm{oz}$

y Least significant difference at $P=0.05$.

*** Significant at $P \leq 0.001 ; \mathrm{NS}=$ not significant at $P \leq 0.05$.

respectively. Nodes that failed to generate a new plant within 4 weeks were considered dead and their total amount (less than $5 \%$ ) is in line with previous incubation studies carried out with the same technique (data not published).

Daughter plants originating from the same stolon were all similar in color, height, and leaf number (data not shown), regardless of original node position in the stolon.

Major differences in daughter plants growth induced by TE treatments were recorded in nodes excised at 4 WAT (Table 2). While the control and plants treated with the labeled rate provided similar aerial part dry biomass production over 4 weeks of incubation, with an average value of $67.8 \mathrm{mg} /$ plant, the $0.075-, 0.15-$, and $0.3-\mathrm{g} \cdot \mathrm{m}^{-2}$ treatments resulted in a significant aerial biomass growth enhancement that reached the average value of $95.7 \mathrm{mg} /$ plant with no statistical difference among the three application rates.

Daughter plants originating from nodes excised at 8 WAT did not show statistical differences between treatments applied on mother plants with an average value of $50.5 \mathrm{mg} /$ plant being recorded.

\section{Discussion}

From this greenhouse trial, it appears the effects of TE application on 'Tifway' hybrid bermudagrass stolons are similar to those reported on leaves and stems. In particular, stolon numbers were unaffected and stolon growth suppression was actually a reduction in tissue elongation with the histological architecture, namely the number of nodes per stolon, being unaffected. Node vitality was unaffected also and these two results account for a number of vital nodes per parent plant that should not be affected by the use of TE, thus 
maintaining propagation capabilities of treated plants.

When considering the recuperative potential of a turf, lateral growth is a key factor and the reduction of stolon elongation could be a drawback of TE application. When applied at labeled rate, TE reduced stolon growth rate only at 2 WAT causing a $24.6 \%$ reduction in mean stolon length. On the other hand, negative effects on lateral spread were not observed at 3 and 4 WAT with stolon growth rate and mean length going back to values that were not statistically different from those recorded in the untreated control. Furthermore, higher rates of application produced a significant reduction of stolon growth rate at 2 WAT, and the effects on stolon mean length lasted until 4 WAT.

Nodes incubated in the trial probably originated under the combined effect of TE, cytokinin-enhanced production, and high availability of TNC with all these compounds being subject to translocation through the stolon vascular system.

Neither node vitality nor daughter plants' parameters showed variations with respect to the location of node excision. Based on this observation, translocation of TE, secondary products, or both in stolons does not seem to determine distinct effects because of the distance from the absorption site of plants and target organs.

Daughter plants originating from nodes excised at 4 WAT showed more vigorous plant growth with higher TE application rates producing an average of $95.7 \mathrm{mg} /$ plant of aboveground dry biomass compared with the average $67.8 \mathrm{mg} /$ plant aboveground dry biomass recorded for labeled rate and untreated control. The postinhibition growth enhancement, also known as "rebound effect," is described in several research works and its occurrence is thought to be due to two concurrent modifications in plant cell activity: complete degradation of TE with cessation of growth inhibition and higher availability of cytokinin and TNC that stimulate and support cell division (Ervin and Zhang, 2007, 2008). In this research, the contribution of reserve carbohydrates from plant tissues connected to the meristematic tissue was reduced by the excision of nodes from internodes, and further research is needed to assess whether small amounts of carbohydrates stored in nodes can play a role in the postinhibition growth enhancement in excised meristems. Besides cytokinin, other hormone modifications could be induced by TE as described by Rademacher (2000) for GA inhibitors. In a study by Tan and Qian (2003), kentucky bluegrass (Poa pratensis L.) plants treated with $\mathrm{TE}$ showed a lower concentration of gibberellic acid $\mathrm{GA}_{1}$, while its precursor $\mathrm{GA}_{20}$ showed a $146 \%$ increased concentration. Once TE is degraded, $\mathrm{GA}_{20}$ is likely to be converted in $\mathrm{GA}_{1}$ with the effect of an overstimulation of cell elongation.

Daughter plants originating from nodes excised at 8 WAT were unaffected by the "rebound effect" with no differences being evident between treated and untreated plants. This result sustains the hypothesis that in both parent plants and daughter plants, following the period of TE effectiveness, a postinhibition growth enhancement occurs and eventually hormone and carbohydrate levels go back to normal values. No permanent modification has been detected in plant following the TE application.

\section{Conclusion}

Under trial conditions, TE application at labeled rate resulted in no effect on stolon production of 'Tifway' hybrid bermudagrass compared with untreated control, while a reduction in stolon growth rate was observed only at 2 WAT. Application at higher rates could reduce recuperative potential while the number of vital nodes was unaffected by all tested treatments. On the other hand, at 4 WAT, application rates higher than labeled rate can produce a postinhibition growth enhancement that could speed up the establishment rate of sprigs harvested from a previously treated turf.

Further research is needed to assess the consistency of these results with field data and with TE multiple applications programs.

\section{Literature cited}

Baldwin, C.M., H. Liu, L.B. McCarty, W. Bauerle, and J.E. Toler. 2006. Effects of trinexapac-ethyl on the salinity tolerance of two ultradwarf bermudagrass cultivars. HortScience 41:808-814.

Baldwin, C.M., H. Liu, L.B. McCarty, H. Luo, and J.E. Toler. 2009. Nitrogen and plant growth regulator influence on 'Champion' bermudagrass putting green under reduced sunlight. Agron. J. 101:75-81.

Beard, J.B. 1973. Turfgrass: Science and culture. Prentice Hall, Englewood Cliffs, NJ.

Bunnel, B.T., L. McCarty, and W.C. Bridges. 2005. TifEagle bermudagrass response to growth factors and mowing height when grown at various hours of sunlight. Crop Sci. 45:575-581.

Ervin, E.H. and X. Zhang. 2007. Influence of sequential trinexapac-ethyl applications on cytokinin content in creeping bentgrass, kentucky bluegrass and hybrid bermudagrass. Crop Sci. 47:21452151 .

Ervin, E.H. and X. Zhang. 2008. Applied physiology of natural and synthetic plant growth regulators in turfgrasses, p. 171200. In: M. Pessarakli (ed.). Handbook of turfgrass management and physiology. CRC Press, Boca Raton, FL.

Fagerness, M.J., D.C. Bowman, F.H. Yelverton, and T.W. Rufty, Jr. 2004. Nitrogen use in 'Tifway' bermudagrass, as affected by trinexapac-ethyl. Crop Sci. 44:595-599.

Fagerness, M.J. and F.H. Yelverton. 1998. Effects of turfgrass growth regulators on lateral development of hybrid and common bermudagrass. Southern Weed Science Soc. Proc. 51:65-66.

Fagerness, M.J. and F.H. Yelverton. 1999. Regulation of 'Tifway' bermudagrass growth and development with trinexapacethyl and paclobutrazol. Southern Weed Science Soc. Proc. 52:68-69.

Fagerness, M.J. and F.H. Yelverton. 2000. Tissue production and quality of 'Tifway' bermudagrass as affected by seasonal application patterms of trinexapacethyl. Crop Sci. 40:493-497.

Fagerness, M.J., F.H. Yelverton, and V. Cline. 2001. Trinexapac-ethyl affects canopy architecture but not thatch development of 'Tifway' bermudagrass. Intl. Turfgrass Soc. Res. J. 9:860-864.

Fagerness, M.J., F.H. Yelverton, D.P. Livingston, and T.W. Rufty, Jr. 2002. Temperature and trinexapac-ethyl effects on bermudagrass growth, dormancy and freezing tolerance. Crop Sci. 42:853858.

Huang, B. 2007. Plant growth regulators: What and why. Golf Course Mgt. 75: 157-160. 
McCarty, L.B., T.G. Willis, J.E. Toler, and T. Whitwell. 2011. 'TifEagle' bermudagrass response to plant growth regulators and mowing height. Agron. J. 103: 988-994.

Rademacher, W. 2000. Growth retardants: Effects on gibberellin biosynthesis and other metabolic pathways. Annu. Rev. Plant Physiol. Plant Mol. Biol. 51: 501-531.
Richardson, M.D. 2002. Turf quality and freezing tolerance of 'Tifway' bermudagrass as affected by late-season nitrogen and trinexapac-ethyl. Crop Sci. 42:16211626.

Tan, Z.G. and Y.L. Qian. 2003. Light intensity affects gibberellic acid content in kentucky bluegrass. HortScience 38:113116.
Waltz, F.C. and T. Whitwell. 2005. Trinexapac-ethyl effect on total nonstructural carbohydrates of field-grown hybrid bermudagrass. Intl. Turfgrass Soc. Res. J. 10:899-903.

Williams, D.L., P.B. Burrus, and K.L. Cropper. 2010. Seeded bermudagrass tolerance to simulated athletic field traffic as affected by cultivars and trinexapac-ethyl. HortTechnology 20:533-538. 